DOI

\title{
ОСОБЛИВОСТІ ЦИРКУМВЕНТРИКУЛЯРНОЇ СИСТЕМИ ГОЛОВНОГО МОЗКУ В ОСІБ ЛІТНЬОГО ВІКУ
}

\section{ВДНзу «Буковинський державний медичний університет»}

○T. С. Комшук

\begin{abstract}
РЕЗЮМЕ.Уходіморфометричногодослідження магнітно-резонанснихтомограмдано комплекснуприжиттєву характеристику вентрикулярної системи головного мозку людини літнього віку. Вивчені гендерні особливості та міжпівкульна асиметрія відповідних показників.

КЛЮчОВІ СЛОВА: вентрикулярна система, літній вік, чоловіки, жінки, МРТ, морфометрія.
\end{abstract}

Вступ. На сучасному етапі розвитку медичної науки помітно зростає роль фундаментальних дисциплін, у тому числі анатомії людини, медичної та інтегративної антропології [1]. Чим точнішими і достовірнішими стають методи медичної візуалізації, тим актуальніше постає проблема правильної інтерпретації та стандартизації даних одержуваного зображення [3, 7].

Введення в медичну практику нових методів нейровізуалізації - комп'ютерної та магнітнорезонансної томографії - змінило принципи діагностики морфологічних змін головного мозку і відкрило нові горизонти у вивченні його будови [2].

Характерні анатомічні особливості органів 3 урахуванням їх індивідуальної мінливості, а також статевих відмінностей, вивчені поки недостатньо. Бурхливий розвиток морфології і фізіології нервової системи відволік увагу дослідників від питань загальної кількісної характеристики мінливості мозку, а це призвело до того, що і до сьогодні у більшості посібників і оглядів наводяться суперечливі і неоднорідні дані про вагу головного мозку і його розміри, особливо про вентрикулярну систему [4].

Головний мозок людини має значну мінливість. Він різниться у чоловіків і жінок, у різних рас, етнічних груп. Ознаки відмінності зберігаються 3 покоління в покоління і можуть бути важливою характеристикою варіабельності мозку людини як біологічного виду [6].

Водночас, практично відсутні роботи із застосуванням класичного методу анатомії «описувально-вимірювального», тобто роботи 3 вивчення індивідуальної мінливості людей із залученням морфометричних методів із використанням методів варіаційної статистики $[5,8]$.

Недостатньо розроблена проблема індивідуального розвитку головного мозку в постнатальному періоді онтогенезу. Процес розвитку людського організму після народження більше вивчений лише щодо періоду дитинства [4] i мало - щодо періодів літнього та старечого віку.
У зв'язку з цим актуальним $є$ вивчення прижиттєвих морфометричних характеристик, насамперед для вентрикулярної системи головного мозку у людей літнього віку.

Робота виконана відповідно до основного плану НДР Буковинського державного медичного університету і $є$ фрагментом комплексної міжкафедральної теми «Закономірності перинатальної анатомії та ембріотопографії. Визначення статево-вікових особливостей будови і топографоанатомічних взаємовідношень органів та структур в онтогенезі людини» (№ державної реєстрації 0110U003078).

Метою нашого дослідження була оцінка морфометричних показників вентрикулярної системи головного мозку за результатами МРТ людей літнього віку (жінки - 56-74 роки, та чоловіки 61-74 роки).

Матеріал і методи дослідження. Обстеження проводили у відділенні променевої діагностики клінічного закладу «Рівненська обласна клінічна лікарня» на комп'ютерному томографі General Electric Healthcare "Signa MRI 1.5T» та у кабінеті магнітно-резонансної томографії клінічного закладу «Луцька міська клінічна лікарня» на комп'ютерному томографі Signa Profile Ce Medical Sistem - 1,5 Тл у стандартних анатомічних площинах (сагітальній, фронтальній і аксіальній). Вимірювання проводили у людей без візуальних ознак органічних уражень головного мозку і черепа.

Проаналізовано 38 томограм осіб літнього віку (14 чоловіків та 24 жінки).

При порівнянні парних показників (бічних шлуночків) вираховували коефіцієнт асиметрії $\left(\mathrm{K}_{\text {асм }}\right)$, який дорівнює різниці між показниками правого і лівого бічних шлуночків поділеної на суму показників правого і лівого шлуночків (у \%).

Результати обробляли методами дескрипційної статистики з використанням t-критерію подібності-відмінності Стьюдента.

Результати й обговорення. Вивчено 13 морфометричних параметрів лікворної системи 
Огляди літератури, оригінальні дослідження, погляд на проблему

головного мозку, а саме розміри бічних, III та IV воду в осіб обох статей літнього віку. Дані предшлуночків головного мозку та довжину водопро-

ставлені в таблиці.

Таблиця. Морфометричні показники шлуночків головного мозку у чоловіків та жінок літнього віку (M $\pm m)$

\begin{tabular}{|c|c|c|c|}
\hline \multicolumn{2}{|c|}{ Морфометричний показник (мм) } & Справа & Зліва \\
\hline \multirow{2}{*}{$\begin{array}{l}\text { Довжина переднього рога } \\
\text { бічного шлуночка }\end{array}$} & 4 & $31,4 \pm 1,8$ & $31,3 \pm 1,4$ \\
\hline & 世 & $29,3 \pm 1,4$ & $30,7 \pm 1,8$ \\
\hline \multirow{2}{*}{$\begin{array}{l}\text { Ширина переднього рога } \\
\text { бічного шлуночка }\end{array}$} & 4 & $8,4 \pm 0,8$ & $8,4 \pm 0,7$ \\
\hline & 世 & $8,1 \pm 0,8$ & $8,2 \pm 0,9$ \\
\hline \multirow{2}{*}{$\begin{array}{l}\text { Довжина тіла бічного } \\
\text { шлуночка }\end{array}$} & 4 & $47,5 \pm 2,3$ & $47,5 \pm 1,7$ \\
\hline & 世 & $44,8 \pm 2,7$ & $45,4 \pm 3,5$ \\
\hline \multirow{2}{*}{$\begin{array}{l}\text { Ширина тіла бічного } \\
\text { шлуночка }\end{array}$} & 4 & $14,6 \pm 0,9$ & $15,4 \pm 0,9$ \\
\hline & 世 & $12,2 \pm 0,8$ & $12,39 \pm 0,7$ \\
\hline \multirow{2}{*}{$\begin{array}{l}\text { Довжина заднього рогу } \\
\text { бокового шлуночка }\end{array}$} & 4 & $34,3 \pm 7,5$ & $39,8 \pm 3,6$ \\
\hline & ж & $36,3 \pm 3,8$ & $37,7 \pm 5,2$ \\
\hline \multirow{2}{*}{$\begin{array}{l}\text { Ширина заднього рогу } \\
\text { бічного шлуночка }\end{array}$} & 4 & $9,6 \pm 1,4$ & $9,4 \pm 1,1$ \\
\hline & ж & $8,7 \pm 1,8$ & $9,2 \pm 2,0$ \\
\hline \multirow{2}{*}{$\begin{array}{l}\text { Довжина нижнього рогу } \\
\text { бічного шлуночка }\end{array}$} & 4 & $46,5 \pm 0,9$ & $45,7 \pm 0,7$ \\
\hline & ж & $45,3 \pm 0,3$ & $44,1 \pm 0,7$ \\
\hline \multirow{2}{*}{$\begin{array}{l}\text { Передньозадній розмір } \\
\text { бічного шлуночка }\end{array}$} & 4 & $99,3 \pm 1,7$ & $102,8 \pm 1,8$ \\
\hline & ж & $96,7 \pm 3,4$ & $96,7 \pm 3,1$ \\
\hline \multirow[t]{2}{*}{ Довжина III шлуночка } & 4 & \multicolumn{2}{|c|}{$30,6 \pm 2,8$} \\
\hline & 世 & \multicolumn{2}{|c|}{$29,9 \pm 3,4$} \\
\hline \multirow[t]{2}{*}{ Висота III шлуночка } & 4 & \multicolumn{2}{|c|}{$17,3 \pm 0,7$} \\
\hline & ж & \multicolumn{2}{|c|}{$17,8 \pm 1,4$} \\
\hline \multirow{2}{*}{$\begin{array}{l}\text { Довжина водопроводу } \\
\text { мозку }\end{array}$} & 4 & \multicolumn{2}{|c|}{$12,2 \pm 0,7$} \\
\hline & 世 & \multicolumn{2}{|c|}{$13,1 \pm 0,7^{*}$} \\
\hline \multirow[t]{2}{*}{ Довжина IV шлуночка } & 4 & \multicolumn{2}{|c|}{$36,8 \pm 1,9$} \\
\hline & 世 & \multicolumn{2}{|c|}{$36,1 \pm 3,3$} \\
\hline \multirow[t]{2}{*}{ Висота IV шлуночка } & 4 & \multicolumn{2}{|c|}{$11,1 \pm 1,0$} \\
\hline & ж & \multicolumn{2}{|c|}{$10,8 \pm 0,9$} \\
\hline
\end{tabular}

Примітки: * - достовірна різниця між чоловіками та жінками, ** - достовірна різниця між відповідними показниками справа та зліва; ч - чоловіки, Ж -жінки.

Аналіз морфометричних показників шлуночків головного мозку, наведених у таблиці, свідчить про наявність певної статевої мінливості вентрикулярної системи головного мозку та міжпівкульної асиметрії.

Найбільша мінливість вивчених нами морфометричних показників спостерігалася при аналізі бічних шлуночків. Встановлено, що довжина переднього рогу бічного шлуночка $\epsilon$ дещо більшою справа у жінок, на 4,6 \%. У чоловіків довжина правого переднього рогу бічного шлуночка була однаковою як справа, так і зліва. У жінок виявлено зменшення довжини правого рогу бокового шлуночка, а лівого - на 1,9 \% порівняно з чоловіками.

Найбільша мінливість вивчених нами морфометричних показників спостерігалася при аналізі бічних шлуночків. Встановлено, що довжина переднього рогу бічного шлуночка $є$ більшою зліва тільки в жінок на 4,6 \% ( $\left.\mathrm{K}_{\text {асм }}=-2,3\right)$, а в чоловіків залишалася однаковою як справа, так і зліва. У жінок виявлено зменшення довжин правого та лівого передніх рогів бічних шлуночків - на 1,9 \% порівняно з чоловіками.

Ширина та довжина передніх рогів бічних шлуночків у осіб чоловічої статі була однаковою $з$ обох боків. У представників жіночої статі ширина бічного шлуночка незначно збільшувалася зліва, на $1,2 \%$.

Довжина тіла бічного шлуночка як справа, так і зліва, $є$ меншою у жінок порівняно з особами протилежної статі, спостерігається міжпівкульна асиметрія із збільшенням даного показника зліва у жінок на 1,5 \%. Ширина тіла бічного шлуночка $є$ більшою зліва в осіб обох статей. Спостерігається певна різниця у ширині тіла бічного шлуночка між чоловіками та жінками із зменшенням даного показника в жінок.

Ширина тіла бічного шлуночка $\epsilon$ більшою зліва в чоловіків. Довжина заднього рогу бічного шлуночка зліва в чоловіків $є$ більшою на 5,3 \%, порівняно з протилежною статтю, а в жінок показник справа більший на 5,5\%. 
Огляди літератури, оригінальні дослідження, погляд на проблему

У чоловіків спостерігається асиметрія зі збільшенням довжини заднього рогу зліва, порівняно 3 правим $\left(\mathrm{K}_{\text {асм }}=-7,4\right)$. У жінок має місце тенденція до переважання показника зліва на 3,7\% ( $\left.\mathrm{K}_{\text {асм }}=-1,9\right)$. Ширина заднього рогу навпаки, в осіб чоловічої статі більша справа, а в жінок - зліва. При порівнянні між статями ширина заднього рогу бічних шлуночків більша в чоловіків як справа, так і зліва на 9,4\% та 2,1\% відповідно.

Довжина нижнього рогу бічного шлуночка більша справа як у жінок $\left(\mathrm{K}_{\mathrm{acm}}=1,3\right)$, так і в чоловіків $\left(K_{\text {асм }}=0,9\right)$. Також відмічена певна статева різниця у показнику як справа так і зліва, зі збільшенням у чоловіків.

Передньо-задній розмір бічного шлуночка більший у чоловіків, порівняно з жінками. При аналізі міжпівкульної різниці даного показника виявлено збільшення його зліва в чоловіків $\left(\mathrm{K}_{\mathrm{acm}}=-1,7\right)$.

Довжина III шлуночка дещо переважає в чоловіків, порівняно з жінками (на 2,3 \%). Статевих відмінностей у ширині III шлуночка не виявлено. Довжина водопроводу мозку є більшою в жінок, ніж у чоловіків. Довжина та висота IV шлуночка мають тенденцію до збільшення в чоловіків на 2,2 \% та 2,7 \% відповідно.

Встановлено кореляційні зв'язки між окремими структурами шлуночкової системи в осіб літнього віку.

У осіб чоловічої статі літнього віку виявлено як прямі, так і зворотні кореляційні зв'язки між різними структурами лікворної системи.

Сильний прямий кореляційний зв'язок спостерігали справа між наступними структурами: довжиною переднього рогу та шириною останнього ( $r=+0,81)$, шириною тіла $(r=+0,94)$ і заднього рогу $(r=+0,99)$ і передньо-заднім розміром $(r=+0,99)$ бічного шлуночка; шириною переднього рогу та шириною тіла $(r=+0,96)$ і заднього рогу $(r=+0,86)$ i передньо-заднім розміром $(r=+0,83)$ бічного шлуночка; довжиною тіла та довжиною нижнього рогу ( $r=+0,85)$ бічного шлуночка; шириною тіла та шириною заднього рогу $(r=+0,97)$ і передньозаднім розміром $(r=+0,95)$ бічного шлуночка; шириною заднього рогу $(r=+0,99)$ та передньо-заднім розміром бічного шлуночка.

Зворотний сильний кореляційний зв'язок виявлено між: довжиною переднього рогу та довжиною тіла $(r=-0,79)$ бічного шлуночка; довжиною тіла бічного шлуночка та передньо-заднім розміром $(r=-0,77)$ і шириною заднього рогу $(r=-0,73)$ бічного шлуночка.

Зліва кореляційні зв'язки були дещо відмінними. Сильна пряма кореляційна залежність спостерігалася між: довжиною переднього рогу та його шириною $(r=+0,75)$, шириною тіла $(r=+0,96)$, довжиною $(r=+0,89)$ і шириною $(r=+0,98)$ заднього рогу бічного шлуночка, довжиною нижнього рогу $(r=+0,82)$, передньо-заднім розміром $(r=+0,83)$ бічного шлуночка. Між шириною переднього рогу та шириною тіла $(r=+0,90)$, шириною заднього рогу $(r=+0,84)$ та довжиною нижнього рогу $(r=+0,99)$ бічного шлуночка. Між шириною тіла та довжиною нижнього $(r=+0,93)$, довжиною $(r=+0,76)$ i шириною $(r=+0,99)$ заднього рогів бічних шлуночків і передньо-заднім $(r=+0,93)$ розміром бічного шлуночка. Між довжиною заднього рогу та його шириною $(r=+0,82)$ і передньо-заднім розміром $(r=+0,93)$ бічного шлуночка. Між шириною заднього та довжиною нижнього рогу $(r=+0,89)$ і передньо-заднім розміром $(r=+0,96)$ бічного шлуночка.

Сильна зворотна кореляційна залежність була знайдена у випадку: довжини тіла і довжини заднього рога $(r=-0,84)$ бічного шлуночка.

Структури, що розташовані центрально, мали пряму кореляційну залежність, а саме сильний прямий кореляційний зв'язок спостерігався у наступних випадках: між довжиною III шлуночка та довжиною $(r=+0,98)$ і шириною $(r=+0,72)$ передніх рогів бічних шлуночків, довжиною ( $r=+0,87)$ і шириною $(r=+0,89)$ тіла, шириною задніх рогів $(r=+0,97)$, передньо-заднім розміром $(r=+0,98)$ бічних шлуночків. Між шириною III шлуночка та довжиною $(r=+0,78)$ і шириною $(r=+0,99)$ передніх рогів бічних шлуночків, шириною $(r=+0,94)$ тіла, шириною задніх рогів $(r=+0,84)$, передньо-заднім розміром $(r=+0,80)$ бічних шлуночків. Між довжиною водопроводу та довжиною нижніх рогів бічних шлуночків $(r=+0,95)$. Між довжиною IV шлуночка та довжиною $(r=+0,99)$ і шириною $(r=+0,79)$ передніх рогів бічних шлуночків, шириною $(r=+0,93)$ тіла, шириною задніх рогів $(r=+0,99)$, передньо-заднім розміром $(r=+0,99)$ бічних шлуночків, довжиною $(r=+0,99)$ та шириною III $(r=+0,76)$ шлуночка. Між шириною IV шлуночка та довжиною $(r=+0,95)$ i шириною $(r=+0,95)$ передніх рогів бічних шлуночків, шириною $(r=+0,99)$ тіла, шириною задніх рогів $(r=+0,98)$, передньо-заднім розміром $(r=+0,96)$ бічних шлуночків, довжиною $(r=+0,90)$ та шириною III $(r=+0,93)$ шлуночка, довжиною IV шлуночка $(r=+0,94)$.

Сильний зворотний кореляційний зв'язок було виявлено між наступними структурами: довжиною тіла бічних шлуночків та IV шлуночка $(r=-0,81)$.

В осіб жіночої статі літнього віку виявлено як прямі, так і зворотні кореляційні зв'язки між різними структурами лікворної системи.

Сильний прямий кореляційний зв'язок спостерігався справа між наступними структурами: довжиною переднього рогу та шириною $(r=+0,88)$, і довжиною $(r=+0,85)$ заднього рогу, і передньо-заднім 
Огляди літератури, оригінальні дослідження, погляд на проблему

розміром $(r=+0,73)$ бічного шлуночка. Між шириною переднього рогу та шириною тіла $(r=+0,97)$ бічного шлуночка. Між довжиною заднього рогу і передньозаднім розміром $(r=+0,95)$ бічного шлуночка; шириною заднього та довжиною нижнього рогу $(r=+0,72)$ бічного шлуночка.

Зворотний сильний кореляційний зв'язок виявлено між: довжиною переднього рогу та довжиною тіла $(r=-0,72)$ бічного шлуночка; довжиною тіла бічного шлуночка та довжиною $(r=-0,73)$ і шириною $(r=-0,73)$ заднього рогу бічного шлуночка.

Зліва усі кореляційні зв'язки були прямими. Сильна пряма кореляційна залежність спостерігалася між:довжиною переднього рогуі довжиною $(r=+0,95)$ та шириною $(r=+0,85)$ заднього рогу бічного шлуночка, шириною переднього рогу $(r=+0,88)$ i передньо-заднім розміром $(r=+0,70)$ бічного шлуночка; шириною переднього рогу та шириною $(r=+0,84)$ заднього рогу бічного шлуночка; шириною тіла та довжиною нижнього рогу $(r=+0,78)$ бічного шлуночка; довжиною заднього рогу та передньо-заднім розміром $(r=+0,83)$ бічного шлуночка.

Структури, що розташовані центрально, мали пряму кореляційну залежність, а саме, сильний прямий кореляційний зв'язок спостерігався у наступних випадках: між довжиною передніх рогів бічних шлуночків та довжиною $(r=+0,85)$ і шириною IV $(r=+0,88)$, довжиною III $(r=+0,85)$ шлуночків; між шириною передніх рогів та довжиною водопроводу $(r=+0,79) ;$ між шириною тіла та довжиною водопроводу $(r=+0,83)$; між шириною задніх рогів бічних шлуночків та довжиною III $(r=+0,97)$ і шириною III $(r=+0,70)$ і довжиною IV $(r=+0,97)$ і шириною IV $(r=+0,94)$ шлуночків; довжиною нижніх рогів бічних шлуночків та шириною III $(r=+0,91)$ i IV $(r=+0,83)$ шлуночків; довжиною III шлуночка та довжиною $(r=+0,99)$ і шириною IV $(r=+0,85)$ шлуночка; довжиною IV шлуночка та його шириною $(r=+0,85)$.

\section{ЛІТЕРАТУРА}

1. МРТ-морфометрия желудочков головного мозга у пациентов с синдромом дефицита внимания и гиперактивности / В. М. Верхлютов, Г. В. Гапиенко, В. Л. Ушаков [и др.] // Журнал высшей нервной деятельности им. И. П. Павлова. - 2009. - Т. 59, № 1. С. 34-44.

2. Норма при КТ- и МРТ-исследованиях / Торстен Б. Мёллер, Эмиль Райф ; пер. с англ. ; под общ. ред. Г.Е. Труфанова, Н. В. Марченко. -2-е изд.-М. : МЕДпрессинформ, 2013.- 256 с.

3. Савельева Л. А. Особенности венозного оттока от головного мозга, по данным магнитно-резонансной ангиографии / Л. А. Савельева, А. А Тулупов // Вестн. Новосиб. гос. ун-та. Серия: Биология, клиническая медицина / 2009. - Т. 7, вып. 1. - С. 36-40.

4. Серков С. В. МРТ в диагностике расширенных периваскулярных пространств головного мозга (результаты собственных исследований и обзор литера-
Сильний зворотний кореляційний зв'язок було виявлено між наступними структурами: довжиною тіла бічних шлуночків та довжиною III ( $\ulcorner=-0,87)$ і IV $(r=-0,86)$ шлуночків.

При проведенні дослідження нами встановлено переважання розмірів структур шлуночкової системи мозку в осіб чоловічої статі, а саме: довжини передніх рогів бічних шлуночків з обох боків, вірогідно довжини тіла бічних шлуночків справа і зліва, ширини задніх рогів бічних шлуночків та довжини нижніх рогів справа і зліва, вірогідно передньо-задніх розмірів бічних шлуночків і довжини III та IV шлуночків.

Виявлена вірогідна міжпівкульна асиметрія зі збільшенням ширини тіла та довжини заднього рогу бічного шлуночка в чоловіків, збільшенням довжини нижнього рогу бічного шлуночка справа як у чоловіків, так і в жінок, збільшення передньо-заднього розміру бічного шлуночка зліва в чоловіків.

Можна припустити, що подібна вікова структурна реорганізація головного мозку зумовлена стійкими метаболічними зрушеннями, що відбуваються в мозку в процесі «старіння» [4].

Висновок. Представлена нами прижиттєва морфометрична характеристика головного мозку людини в період літнього віку та виявлені на її основі критерії вікової реорганізації головного мозку можуть становити інтерес для фахівців в галузі вікової анатомії, нейрофізіології і нейрохірургії, а для фахівців з МРТ-діагностики виступати як еквівалент анатомічної норми ветрикулярної системи головного мозку.

Перспективи подальших досліджень бачимо у вивченні залежності параметрів лікворної системи головного мозку людини від форми черепа, типу тілобудови і статі.

туры) / С. В. Серков, И. Н. Пронин, В. Н. Корниенко // Медицинская визуализация. - 2006. - № 5. - С. 10-25.

5. Труфанов Г. Е. МРТ- и КТ-анатомия головного мозга и позвоночника (атлас изображений) : монография / Г. Е. Труфанов. - 2-е изд. - СПБ, из-во ЭЛБИ-СПб., 2009. -188 c.

6. A common brain network links development, aging, and vulnerability to disease/ G. Douaud, A. R. Groves, C. K. Tamnes [et al.] // Proc. Natl. Acad Sci USA. - 2014. Vol. 24. - P. 73-78.

7. Association between gait variability and brain ventricle attributes: a brain mapping study / C. Annweiler, M. Montero-Odasso, R. Bartha [et al.] // Exp. Gerontol. 2014. - Vol. 57. - P. 256-263.

8. New endoscopic route to the temporal horn of the lateral ventricle: surgical simulation and morphometric assessment / J. J. Sánchez, J. Rincon-Torroella, A. Prats-Galino [et al.] // J. Neurosurg. - 2014. - Vol. 121(3). - P. 751-759. 


\section{Огляди літератури, оригінальні дослідження, погляд на проблему}

\section{GENDER PECULIARITIES OF BRAIN CEREBROSPINAL FLUID SYSTEM IN ELDERLY PERSONS}

\section{@T. S. Komshuk}

\section{HSEIU «Bukovynian State Medical University»}

SUMMARY. In the course of morphometric research of magnetic resonance tomogrames there was given a characteristics of elderly person. There were studies the gender peculiarities and interhemispheric asymmetry of appropriate parameters.

KEY WORDS: ventricular system, elderly persons, MRI, males, females, morphometry.

Отримано 10.06.2015 